\title{
A 2016-os Riói Olimpia sikeressége a sportszer- vezetek bevételi szerkezetének tükrében
}

\section{Success of 2016 Rio Olympic Games as Reflected in the Income of Sport Organizations}

Gósi Zsuzsanna

Testnevelési Egyetem, Sportmenedzsment Tanszék, Budapest

\begin{abstract}
Absztrakt: A magyar sportfinanszírozás az elmúlt években jelentős változáson ment keresztül. Az Olimpián sikeres magyar sportágakra leginkább a 2013-ban elindult KSF program (Kiemelt Sportágfejlesztési program) volt hatással. Ennek hatására jelentősen megnövekedett mind a sportszövetségek, mint a sportegyesületek bevétele. A cikkben azt vizsgálom meg, hogy milyen változás történt a bevételek nagyságrendjében és szerkezetében azoknál a sportegyesületeknél, amelyek versenyzói aranyérmet nyertek a 2016-os Olimpián. Az eredmények azt mutatják, hogy minden klub esetében egyértelmú a bevétel növekedése az elmúlt négy évben. Jellemezóen több mint kétszeresére nótt az összbevétel minden vizsgált sportegyesület esetében. A bevételi szerkezet százalékos arányait vizsgálva a kluboknál csökkent a tagdîj, valamint az önkormányzati támogatás aránya annak ellenére, hogy összegszerúen növekedés mutatható ki mindkét bevételi forrás tekintetében.
\end{abstract}

Kulcsszavak: sportfinanszírozás, bevételi szerkezet, sporttámogatás

\begin{abstract}
Hungarian sport financing has gone through significant changes in the past few years. Mostly the KSF program, which started in 2013, had an effect on successful Olympic sports. The income of sport clubs and sport associations have both significantly increased. In this article I would like to investigate the changes which happened in the scale and structure of incomes in the case of those associations which had a gold-winning athlete in the 2016 Olympic Games. The results clearly show an increase of income in every club's case in the past 4 years. The amount of total income of sport clubs typically doubled in every investigated case. Looking at the percent proportion of income structure, the rate of membership fees and assistance of local governments have decreased despite the increase which can be detected in both income sources.
\end{abstract}

Keywords: sport financing, revenue structure, sports sponsorship

\section{Bevezetés}

A 2016-ban rendezett Olimpián és Paralimpián Magyarország sportolói magas létszámban és sikeresen szerepeltek. Az érmek és a pontszámok tekintetében hosszú időre visszatekintve, az ország méretéhez és gazdasági helyzetéhez viszonyítva kiemelkedő helyezést érnek el a versenyzők. Az öszszes éremszámot tekintve hazánk az első tíz ország között helyezkedik el. A sportszervezetek esetében a finanszírozás az elmúlt években jelentősen átalakult (Gösi, 2015). A cikk kísérletet tesz arra, hogy megvizsgálja a sikeres egyesületek gazdasági mutatóinak változását az elmúlt olimpiai ciklusban. A fókusz az aranyérmet szerzett sportolók egyesületeire, valamint szövetségeire koncentrál.

\section{Módszerek}

A vizsgálat a dokumentumelemzés módszerével készült. A nyilvános törvényszéki adatok, szövetségi adatok és a számviteli beszámolók kerültek elemzésre. A számviteli beszámolók tekintetében a 2012-2015 közötti időszak kimutatásai képezték a vizsgálat tárgyát. A civil szervezetek beszámolási 
rendje és számvitele is megváltozott az elmúlt években. A Civil törvény változásával, valamint ezzel összhangban a civil szervezetekre vonatkozó számviteli törvény változása és a kormányrendeletek következményeként nyilvánosan elérhetőek a gazdálkodásra vonatkozó adatok. A civilszervezetek, köztük a sportszövetségek és sportegyesületek is, egységes formátumban készítik el a beszámolójúkat (Kabulits, 2014).

\section{Eredmények}

\section{A szövetségi bevételek}

A 2016-os Riói Olimpia megítélését kettőség jellemzi. Egyrészt több sportoló kvalifikált a 2016os, mint a 2012-es játékokra, az olimpiai éremtáblázaton a magyar sportolók az előkelő tizenkettedik helyet érték el, és nyolc aranyérmet szereztek. Másrészt viszont szűkült a sikeres sportágak köre, kevesebb versenyző szerzett aranyérmet és érmet, mint négy évvel ezelőtt. A megszerzett olimpia pontok is csökkentek 129 pontról 110 pontra. (Kovács, 2016; Hencsei, 2016). Az is a kettőséget mutatja, hogy míg 2012-ben Londonban öt sportág versenyzői szereztek olimpiai bajnoki címet, ez 2016-ra már három sportágra szűkült. 2012-ben ezek a sportágak az úszás, atlétika, torna, vívás és kajak-kenu voltak. Ezen sportágak közül az atlétika 2016-ban egy bronzérmet szerzett, míg a tornának a legjobb eredménye egy kilencedik helyezés lett. A finanszírozás rendszere az előbb említett öt sportágnak hasonló volt az elmúlt időszakban; mind az öt részese a KSF programnak, s mindegyik szövetség esetében jelentős bevétel növekedés figyelhető meg (Gösi, 2015). Azaz, nem a finanszírozási források szűkülése okozta a sporteredményben bekövetezett változásokat.

A sportszövetségek éves összbevétele (ezer Ft-ban)

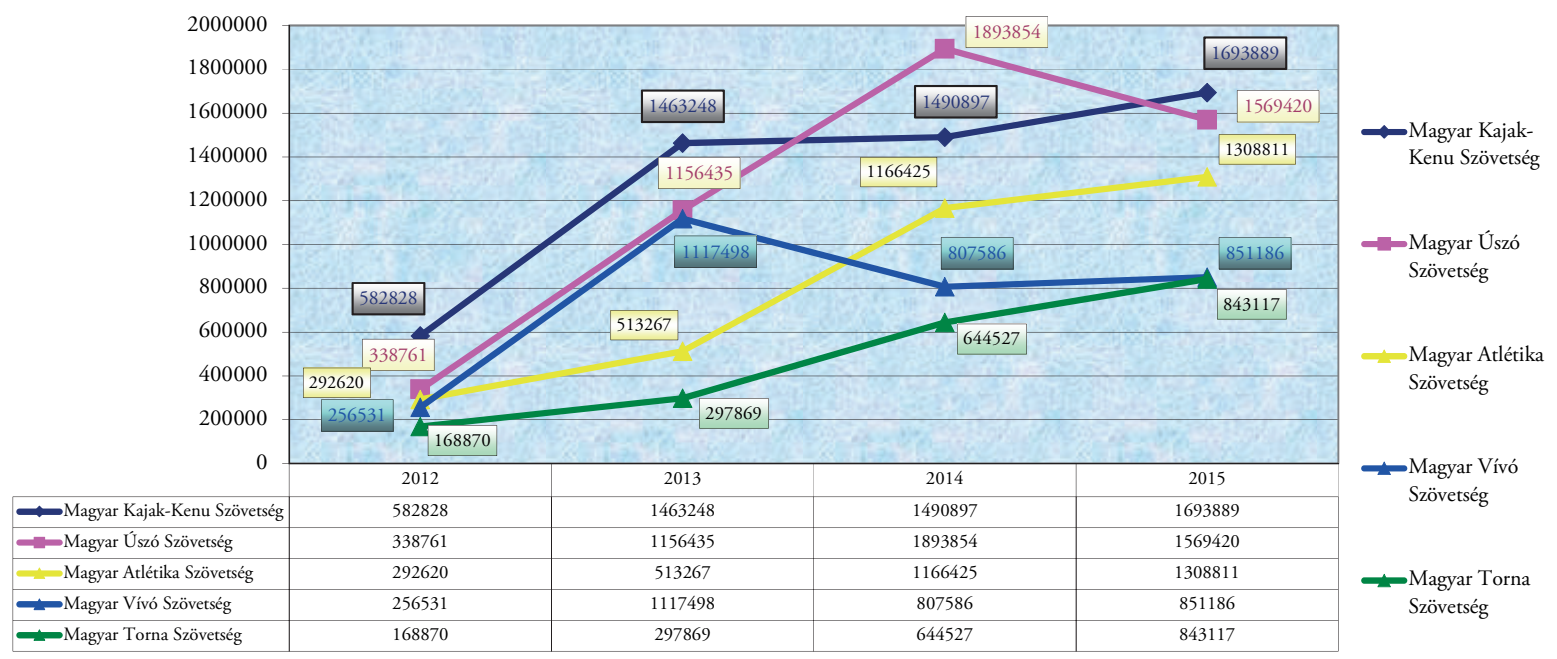

1. ábra. Szövetségi bevételek [Forrás: saját szerkesztés; a szövetségek 2012-2015. évi számviteli beszámolója alapján]

Az ábrán jól látszik, hogy a 2012-es évhez viszonyítva minden vizsgált sportágban jelentős bevétel növekedés a jellemző. Néhány esetben találhatunk kiugró adatokat, de a trendet figyelve egyértelmü a növekedés. A kiugró adatokat egy-egy nagyobb esemény szervezése, vagy nagyobb beruházás okozta. Mind az öt sportágban több mint kétszeresére emelkedtek a bevételek a 2012-es szinthez képest. A bevétel növekedés azonban rövidtávon még nem jelenthet automatikus eredményjavulást a nemzetközi versenyeken, hiszen a sportba befektetett tőke megtérülési ideje hosszútávon érzékelhető (Gősi és Géczi, 2015). A felkészülést annyiban segítette a növekedő bevétel, hogy javultak a feltételek mind létesítmény használhatóság, mind az edzőtáborozási lehetőségek tekintetében. Az utánpótlás nevelő programok fellendítése, a növekvő sportolói létszám hosszabb távon vezet majd csak eredményre. $\mathrm{Az}$ utánpótlás nevelésre fordított összegek hatékonyságát legkorábban a 2020-as, de még inkább a 2024-es játékok után lehet majd értékelni, figyelembe véve azt a tényt is, hogy kivétel nélkül szinte 
az összes sportágban egyre erősebb verseny figyelhető meg, és új nemzetek sportolói jelennek meg a világ élvonalában.

\section{Egyesületi bevételek vizsgálata}

A 2016-os Olimpián szerzett aranyérmek tekintetében az egyesületek közül kiemelkedik a Vasas Sport Club. A nyolc olimpiai és egy paralimpiai arany közül hatot e szervezet sportolói szereztek. Ezen kívül még három klub mondhatja magáról, hogy versenyzői a csúcsra értek. Az egyesületi

2012 London

Bajnokok és klubjaik

\begin{tabular}{|c|c|c|}
\hline \multicolumn{2}{|c|}{ Berki Krisztián } & $\begin{array}{l}\text { Újpesti Torna } \\
\text { Egylet (UTE) }\end{array}$ \\
\hline \multirow[t]{2}{*}{$\begin{array}{l}\text { Kajak } \\
\text { kettes }\end{array}$} & Dombi Rudolf & $\begin{array}{c}\text { Építők } \\
\text { Margitszigeti Diák } \\
\text { KC }\end{array}$ \\
\hline & Kökény Roland & Esztergomi KKSE \\
\hline \multicolumn{2}{|c|}{ Kozák Danuta } & Budapesti Honvéd \\
\hline \multirow{4}{*}{$\begin{array}{l}\text { Kajak } \\
\text { négyes }\end{array}$} & $\begin{array}{c}\text { Fazekas- } \\
\text { ZurKrisztina }\end{array}$ & Győri Graboplast \\
\hline & Kovács Katalin & Budapesti Honvéd \\
\hline & Kozák Danuta & Budapesti Honvéd \\
\hline & Szabó Gabriella & Budapesti Honvéd \\
\hline \multicolumn{2}{|c|}{ Gyurta Dániel } & Jövő SC \\
\hline \multicolumn{2}{|c|}{ Pars Krisztián } & $\begin{array}{l}\text { Szombathelyi } \\
\text { Dobó SE }\end{array}$ \\
\hline \multicolumn{2}{|c|}{ Risztov Éva } & $\begin{array}{c}\text { Debreceni } \\
\text { Sportcentrum SI }\end{array}$ \\
\hline \multicolumn{2}{|c|}{ Szilágyi Áron } & Vasas Sport Club \\
\hline
\end{tabular}

sikerességet árnyalja az a tény, hogy a csapatsportágak versenyzői nem feltétlenül egy klubban készülnek, ez vonatkozik a női kajak négyes tagjaira is.

A bevezetésben említésre került, hogy a legsikeresebbek a Vasas Sport Club versenyzői voltak. Aranyérmet szereztek még a Budapesti Honvéd, az Újpesti Torna Egylet és Graboplast Győri Vízisport Egyesület sportolói. A 2012-es eredményekhez képest itt is szükülés figyelhető meg.

2016 Rio de Janeiro

Bajnokok és klubjaik

\begin{tabular}{|c|c|c|}
\hline \multicolumn{2}{|c|}{ Hosszú Katinka } & Vasas Sport Club \\
\hline \multicolumn{2}{|c|}{ Kozák Danuta } & $\begin{array}{c}\text { Újpesti Torna } \\
\text { Egylet (UTE) }\end{array}$ \\
\hline \multirow{4}{*}{$\begin{array}{c}\text { Kajak } \\
\text { kettes }\end{array}$} & Kozák Danuta & $\begin{array}{c}\text { Újpesti Torna } \\
\text { Egylet (UTE) }\end{array}$ \\
\cline { 2 - 3 } & Szabó Gabriella & $\begin{array}{c}\text { Budapesti } \\
\text { Honvéd }\end{array}$ \\
\hline \multirow{4}{*}{$\begin{array}{c}\text { Kajak } \\
\text { négyes }\end{array}$} & $\begin{array}{c}\text { Fazekas-Zur } \\
\text { Krisztina }\end{array}$ & $\begin{array}{c}\text { Budapesti } \\
\text { Honvéd }\end{array}$ \\
\cline { 2 - 3 } & Koozri Graboplast \\
\cline { 2 - 3 } & Kozák Danuta & $\begin{array}{c}\text { Újpesti Torna } \\
\text { Egylet (UTE) }\end{array}$ \\
\cline { 2 - 3 } & Szabó Gabriella & $\begin{array}{c}\text { Budapesti } \\
\text { Honvéd }\end{array}$ \\
\hline \multicolumn{2}{|c|}{ Szász Emese } & Vasas Sport Club \\
\hline \multicolumn{2}{|c|}{ Szilágyi Áron } & Vasas Sport Club \\
\hline
\end{tabular}

2. ábra. Bajnokok és klubjaik [Forrás: saját szerkesztés]

A táblázat alapján jól látszik, hogy a vidéki egyesületek szinte teljesen eltűntetek a palettáról. $\mathrm{Az}$ olimpiai aranyérmek tekintetében egyértelmű a budapesti fölény. A budapesti egyesületek a jellemzőik alapján a sikergyáros nagy klubok közé sorolhatóak (Bukta, 2013). Területileg az élsport napjainkban egyértelműen Budapest központú válik. Az érmesek és olimpiai pontot szerzők között kicsit nagyobb arányban jelennek meg a vidéki klubok, de a Budapest központúság ott is jellemző. A fenti megállapítás az egyéni olimpiai sportágakra jellemző, a csapatsportok esetében nagyon sokszor ellenkező folyamatok figyelhetünk meg (MOB közlemény, 2013).

Az átfogó kép alapján a három budapesti klub rendkívül sok azonosságot mutat, mind szervezeti felépítés tekintetében, mind bevételi szerkezetben. Bennük közös, hogy mindegyik nagy hagyományokkal, sok szakosztállyal rendelkező sportszervezet. Ezen klubok éves bevétele az utóbbi három évben átlagosan meghaladta az egy milliárd forintot. A győri klub nemcsak a méretében különbözik a többitől, hanem felépítésben is. A vidéki egyesület elsősorban vízi sportokra, ezen belül is jellemzően a 
kajak-kenura specializálódott egyesület, ennek megfelelően a győri klub bevétele „mindösszesen” csak 190 millió forint körül mozgott. A három nagy klub közül a Vasasnak és az Újpestnek tizennyolc, a Honvédnak tizenhárom szakosztálya van, ezek között találhatunk TAO által finanszírozható szakosztályokat, valamint a kiemelt sportágfejlesztési támogatásban érintett szakosztályokat is. A győri egyesületnél a vízilabda található meg, mint TAO által támogatható sportág. A három nagy klub bevételi szerkezete több lábon áll. Egyrészt a látvány csapatsportágak tekintetében számíthatnak TAO bevételekre, több szakosztályuknál kiemelt sportágfejlesztési támogatásra. A 2015-ös évben mindhárom klub kapott 300 millió forint értékben támogatást a következő címszó alatt: a 2015. évi sportszakmai többletfeladatok ellátására és működésre.

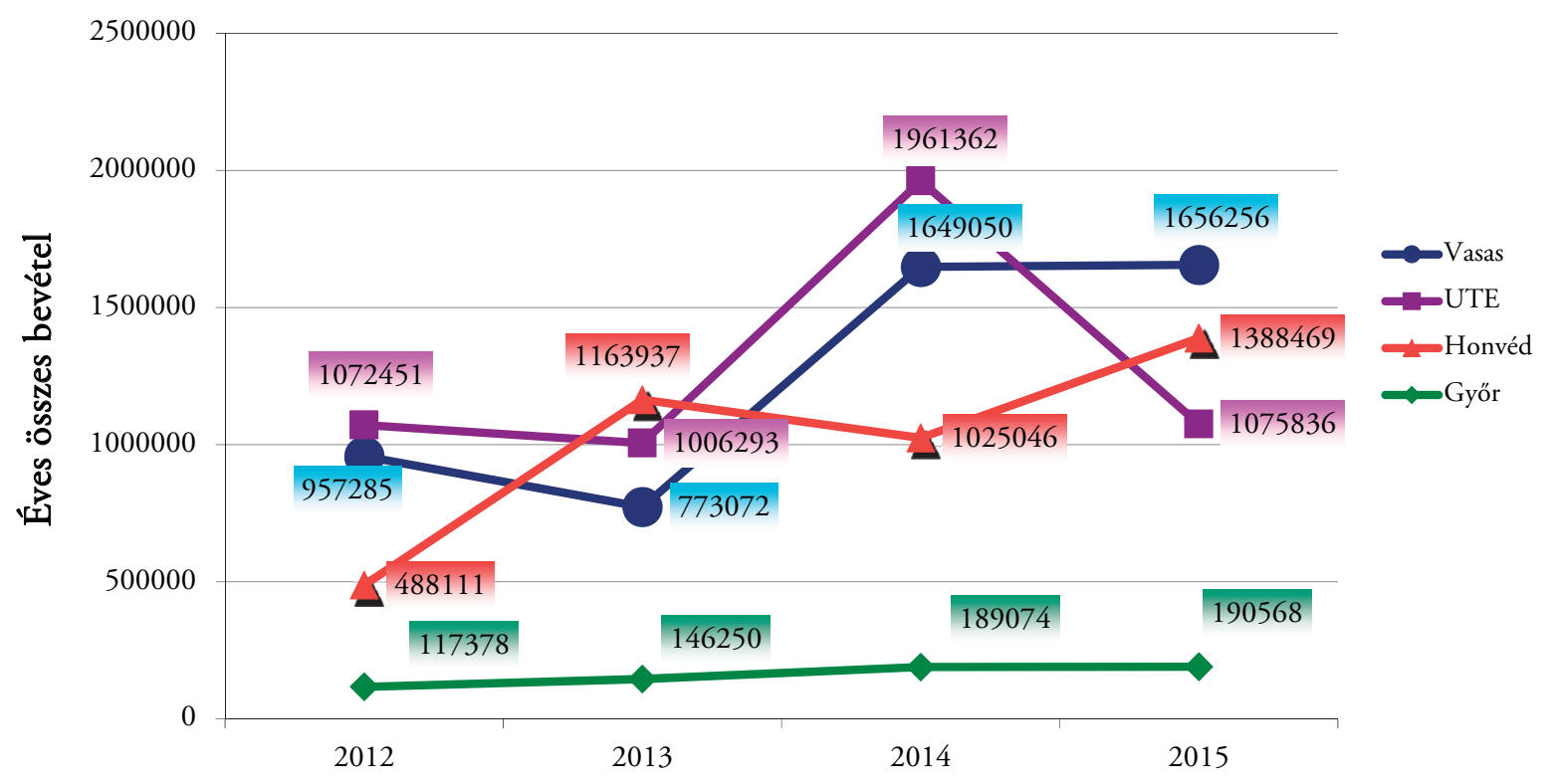

3. ábra. Egyesületi bevételek [Forrás: saját szerkesztés; a klubok számviteli beszámolója alapján, 2012-2015]

A 2012-es bázis évet alapul véve mindegyik klub bevétele jelentős növekedést mutat, köszönhetően a sporttámogatási rendszer átalakulásának. A budapesti kluboknál közös jellemző a jelentős állami, valamint TAO támogatás és a kismértékű tagdíj, illetve önkormányzati támogatás.

A központi költségvetési támogatás aránya a fövárosi klubok elmúlt évi gazdálkodásában jelentős szórást mutat, azonban a 30\% körüli értéket minden esetben eléri, jellemzően azonban 50\% körül mozog. A TAO támogatás mértéke pedig 20\%-ra tehető. Összesítve tehát $50-70 \%$ körüli arányban állami támogatásból vagy az adó átengedésből származó bevétellel gazdálkodnak.

Az UTE esetében a kiugró 2014-es adatot egy rendkívüli támogatás indokolja. Az arányok pontos megállapítását az a tény is nehezíti, hogy bár a számviteli beszámoló tájékoztató adatai között szerepel az a tétel, hogy központi költségvetési támogatás, ennek az értelmezése azonban nem egységes. Van olyan szervezet, amely ide sorolja a szövetségtől kapott támogatást azon elv szerint, hogy a szövetség kizárólag továbbadja az állam által finanszírozott programokra jutó összeget. Néhány egyesület azonban a szövetségtől kapott támogatást, mint egyéb szervezettől kapott támogatás kezeli, így részletesen fel sem tünteti azokat a gazdasági beszámolóban. Ugyanez az eltérés jelenik meg a TAO támogatás tekintetében is, néhány szervezet a számviteli beszámolóban külön bemutatja, más szervezetek esetében csak egyéb forrásokban, jellemzően az egyesület honlapján található róla adat.

\section{Tagdij}

Az egyesületek, köztük a sportegyesületek forrásaiban jelentős szerepet játszhat a tagdíj bevétel. $\mathrm{Ha}$ azonban azokat az egyesületek vesszük górcső alá, melyeknél az olimpián elért siker meghatározó, ott a tagdíj szerepe lényegesen kisebb, mint a szabadidősport egyesületek vonatkozásában. 


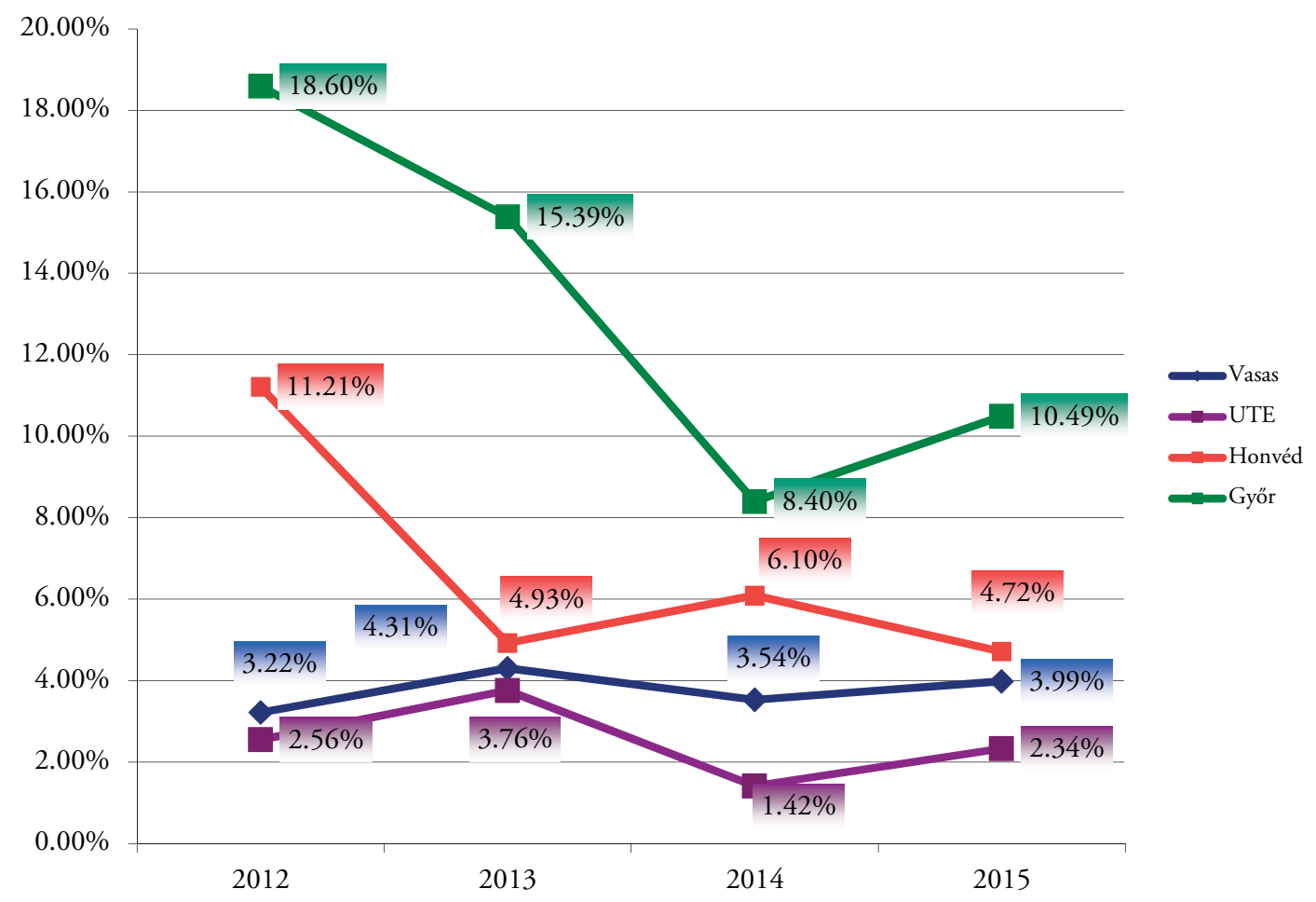

4. ábra. Tagdíj arányok [Forrás: saját szerkesztés; a klubok számviteli beszámolója alapján, 2012-2015]

A budapesti klubok esetében a tagdíj aránya a 2013-as finanszírozási rendszer változása óta a legmagasabb a Budapesti Honvédnál volt, 2014-ben 6,1\%, míg a legalacsonyabb az Újpest esetében, szintén 2014-ben, 1,42\%.

A tagdíjarány jellemzően mindegyik évben (2012-2015) a Budapesti Honvéd esetében volt legmagasabb, míg a sereghajtó az UTE. Az egyes klubokat vizsgálva a tagdíj bevétel a Vasas Sport Clubnál 2012 és 2015 között évről évre emelkedett, míg 2012-ben 30866 ezer volt. Ez 2015-re 66011 ezer Ft-ra emelkedett. Az Újpest esetében a tagdíj összege kiemelkedően magas volt. 2013-ban ez 37879 ezer Ft-ot jelentett.

A következő két évben viszont csökkenést mutatott, 2014-ben 27827 ezer Ft, 2015-ben pedig már csak 25149 ezer Ft. A Honvéd esetében évről-évre folyamatos és kismértékủ emelkedés jelenik meg, ami azt jelenti, hogy a 2012-es 54739 ezer Ft-ról 2015-re 65502 ezer Ft-ra emelkedett. A győri klubban a 2014-es év jelent negatív rekordot 15889 ezer Ft-tal, amely 2015-re 19994 ezer Ft-ra emelkedett, azonban még ekkor sem érte el sem a 2012-es, sem a 2013-as összeget.

\section{Önkormányzati támogatás}

A sporttevékenység esetében a közösségi finanszírozásnak két formája van, a központi (állami) és a helyi (önkormányzati) (Dénes, 2015). Az önkormányzatok sportfinanszírozási gyakorlata a különböző települések között nagy eltérést mutat.

Az önkormányzati támogatások tekintetében a budapesti klubok közül az Újpestnél ez a forma meghaladja a $10 \%$-ot, míg a másik két szervezetnél ez jelentősen kisebb, sőt a Budapesti Honvéd esetében $1 \%$ alatt marad. Az önkormányzati forrásoknál a budapesti klubok vonatkozásában érdemes megemlíteni, hogy nem Budapest Főváros jelenik meg, hanem helyette az egyes kerületek. Az Újpesti Torna Egylet székhelye a IV. kerületben, a Honvéd Sportegyesület és a Vasas Sport klub székhelye a XIII. kerületben található. Az UTE a legalacsonyabb önkormányzati támogatást 2012-ben kapta, közel 139 millió forintot, a legmagasabbat 2013-ban, 239 millió forintot. A Vasas esetében az önkormányzati támogatás 2012-ben és 2013ban 10 millió forint körül volt, míg 2014-ben és 2015-ben 40 millió körüli értékre emelkedett. A Honvéd esetében folyamatosan 10 millió forint körüli összeg körül mozog, de inkább alatta helyezkedik el. Gyorben ez az összeg a 2012-es 39 millió forintról 2015-re 60 millió fölé emelkedett. Arányaiban azonban messze meghaladja a többi klub mutatóját. 


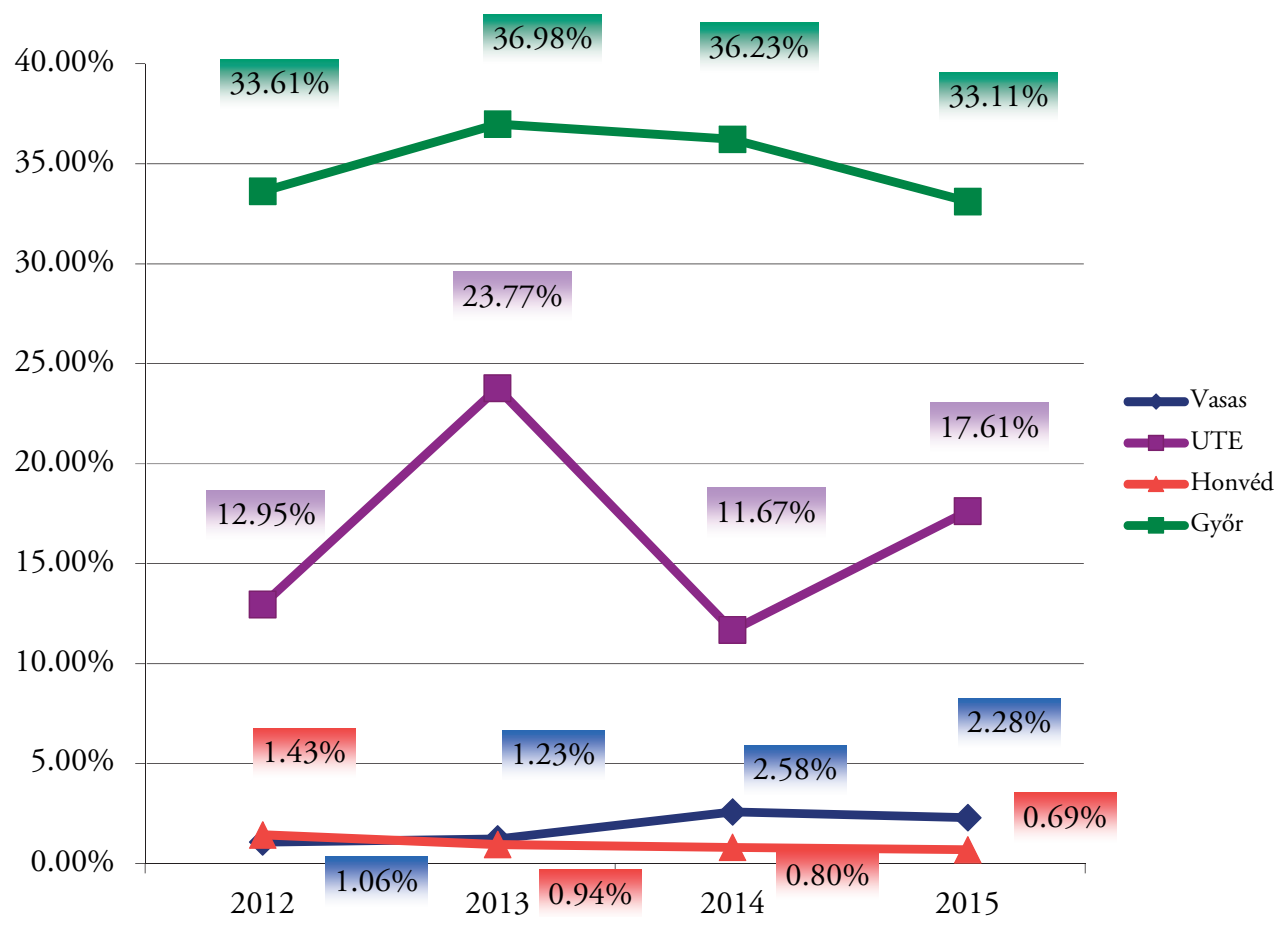

5. ábra. Önkormányzati támogatás [Forrás: saját szerkesztés; a klubok számviteli beszámolója alapján, 2012-2015]

\section{Megbeszélés}

A sportegyesületek, köztük a legeredményesebbek bevétele az elmúlt években jelentősen emelkedett. Ha azonban a bevételszerkezetet vizsgáljuk, látszik, hogy függés alakult ki a közösségi sportfinanszírozás különböző formáitól. A szövetségeken keresztül nyújtott állami támogatás, a társasági adó átengedése, valamint az önkormányzati támogatás a klubok bevételének jelentős hányadát lefedik. Az önálló bevételek, mint a tagdíj, a rendezvényszervezés, valamint a szponzori bevételek aránya rendkívül alacsony.

\section{Irodalom}

1. A budapesti élsport hanyatlása (2013). MOB közlemény. www.mob.hu Megjelenés: 2013.06.04. (Letöltés: 2017.01.10)

2. Bukta Zsuzsanna (2013): Új kihívások a sport civil szférájában: megfelelnek-e a sportegyesületek a közösségi igényeknek? Andragógia és müvelödéselmélet, 1(1): 72-86.

3. Dénes Ferenc (szerk.) (2015): Sportközgazdaságtan; szöveggyüjtemény. 144; TÁMOP4.1.E-15/Konv-2015-0001 projekt; Campus kiadó; Debrecen.
4. Gősi Zsuzsanna (2015): TAO-hatások; új finanszírozási filozófia a sportban. Dibiz - Digital Business, 1(4): 16-17.

5. Gősi Zsuzsanna és Géczi Gábor (2015): Athletes - the invisible reources of sports orgaizations. Apstract, 9(1-2): 105-110. http:// dx.doi.org/10.19041/apstract/2015/1-2/19

6. Hencsei Pál (2016): Olimpiai értékelés. www. jochapress.hu Megjelenés: 2016.08.28. (Letöltés: 2017.01.10)

7. Khaulits Andrea (2014): Civil szervezetek számvitele. In: Lakrovits Elvira (szerk.). Változó civil világ - Kézikönyv civil szervezetek számára. Complex kiadó, Budapest. 299-326.

8. Kovács Tamás (2016): A nyolc riói aranyérem és ami mögötte van. Előadás kivonat. Elhangzott: Vitafórum a Rió Olimpia szereplés tükrében 2016.10.06; www.magyaredzo.hu (Letöltés: 2017.01.05)

9. Nemzetek viadala az ötkarikás játékokon (2008). KSH számlap módszertani kiadvány. http://www.ksh.hu/szamlap/olimpia_via.html Megjelenés: 2008.08. (Letöltés: 2017.01.05) 